\title{
Reconstructing Multiculturalism in Malaysia through Visual Culture
}

\author{
Noraini Md. Yusof \\ Esmaeil Z. J. \\ Institute of Malaysian and International Studies (IKMAS), \\ National University of Malaysia (UKM)
}

Doi: $10.2478 / \mathrm{mjss}-2018-0078$

\begin{abstract}
The terms 'ethnicity' and 'race' bear social and political importance in a multicultural society. Introduced in Malaysia by the British back in the colonial era, these terms have been influencing the politics of the state and everyday life of the grassroots. Since the early days of independence, Malaysia has been witnessing ethnic conflict and right from the very beginning of making a new Malaysia, the Malaysian governments have introduced concepts and plans to eradicate the ethnic conflict but it has not been very successful although the country boasts of its racial stability. Multiculturalism in Malaysia still remains an ambivalent nationalist project. In fact, the road to a collective national identity through multiculturalism is paradoxical. This paper examines how visual culture can help reconstruct a multicultural society and argues that Malaysia's plan in creating a national identity will remain a myth as long as one ethnicity and its values are more important than other ethnicities. It also investigates whether a collective identity is really needed for a multicultural country such as Malaysia.
\end{abstract}

Keywords: ethnicity, race, conflict, multiculturalism, visual culture,

\section{Introduction}

In a multicultural nation, the terms 'ethnicity' and 'race' bear social and political importance. Introduced to Malaysia by the British colonial administration, these terms have always been hot topics of discussion in many of the political and social gatherings. This colonial legacy was wellcultivated in the postcolonial Malaysia and made a dramatic impact on the politics and the everyday lives of its people. Malays, Chinese, Indians, and other ethnic groups continue to live in the same society but each group tend to socialize and operate within their own separate 'compartment'; they may hold functions together or even celebrate festivals, but these celebrations by no means suggest embracing each other's values or the values of total unity. Since its independence in 1957, Malaysia, dominated politically by ethnic Malays, has always been struggling to introduce concepts that promote 'unity in diversity' in its multicultural society to form a 'national identity'. These concepts were allegedly introduced and implemented to preserve the rights of the different ethnic groups in Malaysia and to push Malaysia forward into becoming a real melting pot. These concepts are viewed as approaches that are capable of harmonizing the society as one functioning unit without considering the background of different traditions and cultures. From the New Economic Development (NED) introduced in 1971 to Vision 2020 through Islam Hadhari and 1Malaysia, the Malaysian governments have been trying to tackle the problems of racial tension to achieve national unity. However, the ethnocentricity is still conspicuously present in Malaysia and it is usually furthered by racial stereotypes.

That is the reason Malaysia has been described as an 'ethnic salad bowl' rather than a melting pot as a true version of multicultural society. Despite the governments' efforts in instilling unity amongst the people, the national identity project remains as elusive as ever. Achieving national unity 
in a country where "each ethnicity has its own unique culture and heritage, such as language, belief system, tradition, and religion, is a strenuous task" (Zeiny \& Yusof, 2015, 130); however, they are the stock in trade for a multicultural society. The current Malaysia's racial tolerance is nothing but a fear that the 1969 riot may reoccur. There is, certainly, an urge to comprehend the patterns, dynamics, and inclinations of how each ethnic group relate, perceive and act towards each other in the process of managing and stabilizing the differences among the multi-ethnic groups (Salfarina, Mohd. Zaini, Azeem Fazwan, 2009). Moreover, a deeper sense of understanding, togetherness, and sharing of common values amongst the society's different ethnicities should be nurtured to achieve multiculturalism. To help the government create a multicultural society, visual media can come in handy to educate the ordinary people by promoting cross-cultural understanding, tolerance and acceptance of other ethnic groups, and their cultures and religions. The Malaysian governments have been using various types of visual media in promoting the standards of multiculturalism in the society. Currently, media organizations, in fact, play key roles in delivering and spreading the information about the policy of the government to the Malaysian society. This paper discusses the meaning of multiculturalism in the context of Malaysia and demonstrates how the visual culture can reconstruct multiculturalism in its true sense of the term.

\section{Ethnic Conflict}

Throughout history, ethnic conflicts have long been part of national and international politics. From the ethnic war in Somalia, the Kurdish struggle for autonomy in Iraq and Turkey through the insurrection in Chechnya and the conflict in Rwanda to the racial conflicts in Southeast Asia, ethnic conflict can be seen and felt in galore. Before delving into the ethnic conflict in Malaysia, a definition of ethnic group should be in order. According to People \& Bailey $(2006,355)$, "an ethnic group is a named social category of people based on perceptions of shared social experience or ancestry." Members of these ethnic groups view themselves as sharing and enjoying common cultural traditions and history that differentiate them from other ethnic groups. Thus, ethnicity is a term that denotes a sense of collective belongings based on common language, descent, history, culture, race, and religion or an amalgamation of these traits. The identity of each ethnic group possesses a powerful psychological or emotional element that categorizes the people into 'us' and 'them.' Derived and informed by the social and individual representations, people of these ethnic groups develop a preferred mode of interactions which has a dramatic impact on the formation of their behavior and the way they interpret their environment. This preferred mode of interaction and the way they interpret their environment may lead to ethnic conflict in an ethnic diversity environment such as Malaysia.

Ethnic conflict is defined as "any episode of sustained violent conflict in which national, ethnic, and religious or other communal minorities challenge governments to seek major changes in status" (Bates et. al. 2003). The authorities participated in the planning for making a postcolonial Malaysia were cognizant of the fact that they were inheriting a "volatile racial/cultural social structure that had been constructed and defined by the British" (Gudeman, 2002, 139). From the very beginning of the formation of the independent nation-state, Malaysia aimed for establishing a prosperous and successful multicultural society containing the three "traditionally isolated and mutually distrustful ethnic/cultural groups" (Gudeman, 2002, 139) namely the Malays, the Chinese, and the Indians. Malaysia boasts of its racial stability and highlights it as a success of the country. The evident diversity in the ethnic fabric of Malaysians is, oftentimes, acknowledged and celebrated, especially in its tourism industry with the slogan 'Malaysia, Truly Asia.' However, it has never been totally successful in achieving this goal; the nation's ethnic fragility and the growing polarization amongst the three major races still remain the main concerns for politicians and the people. These concerns are rampant everywhere in social, political and economic debates.

Indeed, ethnicity has been confirmed as the dividing line in Malaysia where members of ethnic groups identify themselves with their own culture, mother tongue and the locality. Thus, this strong link to one's own ethnic community does not allow for the emergence of national entities such as national identity, culture, politics and economy to suit each community's interests (Deutrsch, 1963, 11). This strong adherence to one's own ethnicity arises from the lack of knowledge about other 
ethnic groups beyond the prejudices and racial stereotypes present in each community. The British colonial policy of 'divide and rule' merely left a symbolically plural society in which there is no interaction among the various ethnic groups. Each of these ethnic groups would fight for their social rights to practice their tradition, cultures and rituals. One way to preserve the culture is through language and education. Therefore, almost all the Malay students prefer to study in Malay schools while the Chinese and Indians have a tendency to go for the vernacular school where their mother tongue is the medium of instruction. This system of education creates a feeling of biasedness and prejudice amongst the students towards various ethnic groups (Khalim \& Norshidah, 2010). Hence, the prejudice is developed from the school days and will continue to grow.

To mingle the students, the Malaysian government introduced 'Vision School', in which the three types of Malay, Chinese, and Tamil schools clustered in a common area, providing an opportunity for interaction among the ethnic groups (Choong, 2008). The 'Vision School' was not favored and raised so many eyebrows because the medium of instruction was Malay. Many Chinese and Indian associations strongly objected as they feared that the use of Malay language would threaten the progress of vernacular schools and would cause the mother tongue to disappear (Kua, 2007). The Malaysian governments have been seemingly concerned with the equal distribution of resources and opportunities for the Malays, Chinese and Indians. They are treated pluralistically as each of these ethnic groups is allowed to keep its cultural identity through the retaining of their ethnic languages, religions and traditions. However, what worries the Chinese and Indians is the privilege given to the Malay. To raise their social, economic and educational status in the hope of compensating the social inequalities culminated in the anti-Chinese race riots in 1969, the considerable and disproportionate resources have been directed towards Malays. The Malays control the political power as well. That is why many ethnic Chinese and Indians are unhappy with the privileges given to Malays in business, jobs and education. Thus the question that should be addressed here is given the ethnic conflict, will Malaysia be ever capable of achieving 'unity in diversity'?

\section{Multiculturalism in Malaysia}

The term 'multiculturalism' is an odd, pluralized and a vague word which carries different meanings in paradoxical nature (Bennett 1998). It is, argues Calhoun $(1996,1)$ an "argument for diversity often rooted in a claim of integral singularity." It explains the presence, approval, or promotion of several cultural traditions and rituals within a single territory, usually considered in terms of the culture associated with an ethnic group. It was first coined in 1965 by the Canadian Royal Commission as a proposal to resolve the ethnocentric nationalist and the exclusionist policies in Western liberal democracies, particularly in dealing with managing diversity and cultural differences (Loo, 2012). From then onwards, multiculturalism has become an ideology in politics that although cultures are distinct, they are of the equal status. As noted earlier, 'multiculturalism' means different things in different contexts. For example, in Canada and Australia, it is used exclusively to refer to immigrant groups. At the other end of the spectrum, in Latin America, by contrast, it refers to indigenous groups and not to immigrants. In some countries such as Malaysia, it is used as an umbrella term to cover all forms of ethno-cultural diversity. Multiculturalism can also refer to a statistical fact, a specific set of philosophical notions and ideas, or a particular orientation by government or institutions toward a diverse population (Bloemraad, 2011).

Considering these definitions, multiculturalism becomes a challenge for governments to synchronize the different cultures, ethnicities and their practices into a peaceful symbiosis within a political territory. A case in point is the Netherlands with decades of experiencing and leading the world in multiculturalism but has now left the policies of multiculturalism in favor of integration. Multiculturalism might not be always the solution as it usually separates people and keeps them in their own community which results in racial and religion conflict (Kamarudin, 2015). Now concerns over multiculturalism are part of the political mainstream in all Europe. In October 2010, Angela Merkel, the German Chancellor, announced that multicultural policies became a failure in Germany. In February 2011, Nicolas Sarkozy, the French President, had the same view on multiculturalism and called it a failure, and David Cameron, the British Prime Minister also accused his country's policy of multiculturalism for not being able to promote a sense of common identity and causing 
Muslim segregation and radicalization (Bloemraad, 2011). These governments claim that multiculturalism weakens the social cohesion and local cultural values and opine that integration is a better way than multiculturalism. For example, the Dutch government issued a new integration bill on June 16, 2015 that reads:

The government shares the social dissatisfaction over the multicultural society model and plans to shift priority to the values of the Dutch people. In the new integration system, the values of the Dutch society play a central role. With this change, the government steps away from the model of a multicultural society. (Cited in Kamarudin, 2015)

It seems Malaysia has fallen into the same trap of leaving multiculturalism for integration or 'unity in diversity.' It has been promoting itself as a multicultural society but the country has always been prioritizing Malays and Malay values. Malaysia has, in fact, undergone a long process of negotiation between the different ethnic groups represented by their own political parties. This prioritization began from the time when they picked up what the British have left: the 'Three Cultures' model which only recognized the three ethnicities of Malay, Chinese and Indians. Back in colonial time, each group was administered and treated differently by the British. People were interested in defining themselves as a member of the ethnicities to be recognized by the colonial authorities (Gudeman, 2002). In fact, the prioritization of Malay and Malay values was agreed upon by the elite representatives of the Malays, Chinese, and Indians when they gathered together to make a single multicultural society with a common identity. They have chosen Islam as the religion of the state, Malay was chosen as the national language and it was agreed that the Malay majority hold the political power. In return for "giving Malay language and culture priority in the new state, the Chinese and Indian peoples were granted full citizenship for the first time and guaranteed freedom of religion and the right to practice their culture" (Gudeman, 2002, 142). This sort of policies in a multicultural nation conjures up Phillips' idea of multiculturalism:

Exaggerates the internal unity of cultures, solidifies differences that are currently more fluid, and makes people from other cultures seem more exotic and distinct than they really are. Multiculturalism then appears not as a cultural liberator but as a cultural straitjacket, forcing those described as members of a minority cultural group into a regime of authenticity, denying them the chance to cross cultural borders, borrow cultural influences, define and redefine themselves. $(2007,14)$

Thus, the policies of multiculturalism began from the path of building a new nation after the political independence when they just wanted to create a cohesive nation-state through cultivating a single and homogeneous national culture. This is usually the case which happens following decolonization as talks about "multiculturalism and pluralism was often discouraged, as states attempted to consolidate themselves as unitary and homogenous nation-states" (Kymlicka, 2005, 1). Therefore, one of the immediate concerns Malaysia had after decolonization was how to modify a plural society into a unitary nation-state (Wang, 2001). Continuing to date, this Malaysia's brand of multiculturalism, which simply means management of diversity, is rather distressing. The chief objective of constructing a multicultural nation in Malaysia was to keep national integration in which all these different and distinct cultural communities could live in one society while maintaining their own original identities. However, there have been always barriers that stymie the achieving of this goal. Malaysian governments work hard to create one nation out of the three racial/cultural groups. Steps have been taken to eradicate the barriers amongst the ethnic groups in Malaysia. The New Economy Policy (NEP), Vision 2020, Islam Hadhari, and 1Malaysian concept are all plans with the same objective of creating a single nation by encouraging unity in diversity.

Malaysia has been successful to some extent in achieving this goal by creating contact amongst members of different ethnic groups in the workplace, schools and neighborhoods which resulted in forming lasting bonds amongst the three ethnic groups. But despite this progress, Malaysia is still uncomfortable with multiculturalism. This discomfort with multiculturalism is apparent when the interpretations of multiculturalism do not fall beyond the conventional discourse of "unity in diversity." Part of this discomfort could be due to the fact that the core ethnic identities exist in the current Malaysia and its Constitution constructed by the British and the British-trained 
anthropologists is still in fashion. In the context of Malaysia, the colonial knowledge "not only elaborated and explained about but also sustained and justified the whole concept of plural society through the construction of essentialized ethnic categories...Nation-states... have become the natural embodiments of history, territory and society built entirely on colonial knowledge" (Shamsul A.B. 1999, 152). He further explains that race and ethnicity in Malaysia should not only be examined from the viewpoints of 'authority-defined' social reality but also from the viewpoints of 'everyday-defined' social reality which is encoded in popular visual or verbal media (1999). In the light of this, next section is examining the visual culture in Malaysia and demonstrates how visual culture can help reconstruct a multicultural society.

\section{Visual Culture in Malaysia}

The proof of cultural existence lies in everyday practices of peoples from the four corners of the world. The language, religion, tradition, and local practices of rituals are just some aspects of culture which could be taught and learned. Individuals are not born with inherent and predestined cultures. They learn their culture through messages communicated to them (Samovar \& Porter, 2001). Culture is a complex term and has been defined differently but all share the element of 'learned' in their definitions. Culture is not static as the nature of culture, argues Tomlinson $(1999,144)$, is "fluid, dynamic, protean, ever changing - and at no point in history [is] fixed, established [and] static." Thus, it can be argued that visual culture, as an offshoot of culture, possesses the potential to teach, solidify, and reconstruct certain cultural practices in a multicultural nation such as Malaysia. The Malaysian governments have apparently worked hard to promote ethnic harmony. The rhetoric of multicultural diversity is abundant in media promotion of Malaysia as a multicultural society.

Visual media in Malaysia can be a great help in constructing a multicultural society, something that Malaysia is in dire need for its multicultural nation. Identity is malleable and continuously contested and negotiated. This is even more so for societies in multi-ethnic/cultural countries emerging from colonial experiences. To construct national identity and to promote cross-cultural understanding in the multicultural Malaysia, various types of visual media have been recruited such as television programs, advertisements, and films. As a visual medium, television acts as a solid socialization agent that produces a vicarious social contact setting through which audiences construct their social reality and form their perspectives towards other social groups (Fujikoa, 1999). Television has been a state privilege in Malaysia since 1957 and has always been instrumental in fashioning and demonstrating public culture. In Malaysia, the authorities' perspective towards the role that television can play is that of a functioning tool for promoting national development, national harmony and national security (Annuar, 2002). The television airs programs in which the representatives of the three ethnic groups are shown smiling and singing together. During Muslim holidays, Chinese and Indian are shown as honoring the events and during Chinese and Indian holidays, Muslim Malay extends the same respect and cordiality but these are not very common practices in Television.

Even in efforts to promote 'unity in diversity' such as the above-mentioned example, the Malaysian television programs oftentimes represent the Malays as the superior race which results in creating sacred and non-sacred circuits of cultures (Khattab, 2006). This is because the state television tends to accentuate Malay values in a hegemonic and monolithic term. For instance, the television cartoon of Upin and Ipin which has been produced to educate the children on the ideal interaction amongst the three ethnic groups gained popularity for its moral contents and Islamic values. The notion of propagating national identity based on the superiority of the 'Malay race' perpetuates to surface media representations in the current Malaysian television. More often than not, the state television heedlessly and disrespectfully disavows the values of other ethnic groups while Islamic values and Malay supremacy are the backbone of television discourses and symbols (Khattab, 2015). Unfortunately, across all media including television, public and private, narrowcasting of content based on ethnic groups has become the norm developing an ethnically targeted television programming. Just akin to state policies such as the New Economic Policy and Vision 2020, the programs aired on Malaysian television also deepen group identity and privileges the Malays. The national broadcast industry of Malaysia is certainly a Malay business corporation 
which is built to celebrate Malay national values. Television programs, films, and advertisement are all visual medium that can assist the governments in trying to shift the mentality of Malaysians from tolerance of differences to acceptance. Multiculturalism fails if the general trend is tolerating each other because tolerance "bears an undertone that people are too much exposed to an agonizing or unpleasant condition due to their religious and ethnic differences" (Zeiny \& Yusof 2015, 131). However, acceptance denotes that all the ethnic groups in Malaysia accept and understand the diversity of Malaysian multiracial nation; this could be an asset to a multicultural country.

What seems to be the main problem in constructing and reconstructing the Malaysian nationhood is "determining the right proportion of Islamic values, Malay traditional values, Chinese and Indian values for a perfect national blend to be circulated via national television" (Khattab, $2015,140)$. The policies of the national broadcasting industry made the minorities remain as peripheralized national mediated symbol (Morley, 2004) until independent and fair-minded producers and filmmakers come aboard. One of these independent filmmakers who tried to explore the rising ethnic and cultural divides of the Malaysian nation with her films is Yasmin Ahmad. Ahmad understands well that film can be an important vehicle for bringing unity in diversity. She premiered her first feature film, Sepet in 2004 which has drawn significant attentions. It is a film about an interethnic romance between a Chinese boy and a Malay girl which raised so many eyebrows. The film was criticized on a televised panel as "the corruptors of pollutants of Malay culture" (Nizam Abdullah, 2006, 8). One of the panelists asked "how Orked, a Malay girl who has a firm religious education, could be involved with Jason, a Chinese pirated CD and VCD seller who could be regarded as an infidel" (Nizam Abdullah, 2006, 8). In the same panel, Ahmad was labeled as a "corruptor of culture."

This is the film that set an example of a multicultural society but it has been criticized because the Malay values are not highlighted in the film. Ahmad merely tries to deal with the issue of multiracial confrontations in a way that she sees as exemplary for Malaysia. Conforming the film to Malay Islamic values and standards would have restricted the vastness of her exploration. She avoids depicting the typical cliché of harmonious Malaysian nation, and adopted a different strategy by "challenging her audience to ignore the differences not only in race, but in religion, between her characters" (Al Almin, 2008, 2). This film and her other films are openly criticizing Malaysia's failure in creating a multicultural society where the three ethnic groups are equally treated. Her films and films of that ilk do have the power of constructing a multicultural society where all the ethnic groups enjoy the same status. Films play a significant role in creating a multicultural nation by displaying exemplary of solidarity and equality. For Malaysian films to be seen as a force in constructing the multicultural society, they should be first acceptable to all Malaysians as a reflection of themselves. Films like Yasmin Ahmad which explore different ethnicities as their main theme can be educative and informative so much so that the audience follow and adapt in their real life.

\section{Conclusion}

Malaysia has always been promoting itself as a multicultural country, yet it is still uncomfortable with multiculturalism. That is why since its independence, Malaysia has introduced different plans and concept to promote national unity and 'unity in diversity'. Although racial stability remains a hallmark of Malaysia's success as a nation, the seemingly growing polarization among the three ethnic groups is a growing concern. Diversity, dialogue and peaceful co-existence are momentous themes in Malaysia, and national unity continues to be the overriding objective of the country. Ethnic conflict is inevitable in a country like Malaysia where there is a multi-ethnic, multi-lingual, multi-cultural and multi-religious composition of the population. However, in engineering change for Malaysia, visual culture has the power to shape and shift peoples' perception towards certain issues and in this case it can educate acceptance of each other's ethnicity and reconstruct a multicultural society. However, the current Malaysian television programs and films, in which the Malay supremacy and Malay values are always highlighted, do not seem to be a force in making multicultural society. Films like Yasmin Ahmad's are certainly conducive in reconstructing a multicultural society but there are just few of them which usually face strong criticism. If the current television programs and films mirror the Malaysian society, then it is apparent that the social face of 
Malaysia needs to be reconstructed. The plans to create a national identity for a multi-ethnic/culture Malaysia seems nothing more than a myth as long as the Malays are given the superiority. But for national unity to occur, integration is a sine qua non to create a collective identity which begs the questions: Does Malaysia really need a collective identity? Does collective identity make sense in a multicultural nation?

\section{References}

Al Amin, F. A. M. 2008. Controversies surrounding Malaysians independent female director Yasmin Ahmad's first film, Sepet. 17th Biennial Conference of the Asian Studies Association of Australia.

Annuar, M. K. 2002. 'Defining democratic discourses: the mainstream press' in K. W. F. Loh \& B. K. Khoo (eds.) Democracy in Malaysia: Discourses amd Practices. Richmond, Surrey: Curzon Press, pp. 138-64.

Bates, R. H.; Epstein, D. L.; Goldstone, J.A; Gurr, T.R; Harff, B; Kahl, C.H; Levy, M.A; Lustik, M; Marshall, M.G; Parris, T. M; Ulfelder, J and Woodward, M. R.. 2003. Political Instability Task Force Report: Phase IV Findings.

Bennett, D. 1998. Multicultural states: Rethinking difference and identity. Routledge, London.

Bloemraad, I. 2011. The Debate over Multiculturalism: Philosophy, Politics, and Policy. Migration Policy Institute. Available from http://www.migrationpolicy.org/article/debate-over-multiculturalism-philosophypolitics-and-policy

Calhoun, C. 1996, Multiculturalism and nationalism, or, why feeling at home is not a substitute for public space. Available from <http://www.ssrc.org/calhoun/wpcontent/uploads/2010/11/Multiculturalsim-andNationalsim.pdf>

Choong, L.K.2008. Philosophy and Education in Malaysia. Kumpulan Budiman Sdn. Bhd, Kuala Lumpur.

Deutsch. K.W.1963. 'The Study of Nation-Building, 1962-1966', in Deutsch, K.W. \& Foltz, W.J (eds) NationBuilding. Chicago: Adline Atherton Press.

Fujioka.Y.1999.Television portrayals and African-American stereotypes: Examination of television effects when direct contact is lacking. Journalism \& Mass Communication Quarterly, Vol. 76 (1), pp. 52-75.

Gudeman, R. H. 2002. Multiculturalism in Malaysia: Individual Harmony, Group Tension. Macalester International, Vol. 12 Malaysia: Crossroads of Diversity in Southeast Asia.

Kamarudin, R. P. 2015. Why Multiculturalism does not work. Malaysia today. Available from http://www.malaysia-today.net/why-multiculturalism-does-not-work/

Khalim, Z. \& MS Norshidah 2010. Ethnic Relation among the Youth in Malaysia: Toward Fulfilling the Concept of One Malaysia, Centre For General Studies (PPU) / Institute of West Asian Studies (IKRAB), Faculty of Education, Universiti Kebangsan Malaysia.

Khattab, U. 2006, "Non" mediated images: Public culture and (state) television in Malaysia', International Communication Gazette, vol. 68 (4), pp. 347-361.

Khattab, U. 2015. Unpacking multiculturalism and Islam in Malaysia, in Tay, J \& Turner, G. (eds) Television Histories in Asia: Issues and Contexts. Oxon, United Kingdom: Routledge. Pp, 127-143.

Kua, K.S. 2007. Racial Eyesores on the Malaysian Landscape. Available from: http:malaysiakini.com.

Kymlicka, W, \& He, B. 2005, 'Introduction', in W Kymlicka \& B He (eds), Multiculturalism in Asia. Oxford University Press, New York, pp. 1-21

Loo, H. C. 2012. Recentring Multiculturalism in Malaysia: Nationalist Encounters and On-Screen Exchanges. Official Conference Proceedings. The Asian Conference on Arts and Humanities.

Nizam Abdullah, M.A. 2006, 'Fenomena Seni', Utusan Malaysia, 26 April, p. 8.

Peoples, J. and Bailey, G. 2006. Humanity: An Introduction to Cultural Anthropology. Belmont, CA: Thomson Wadsworth

Phillips A. 2007. Multiculturalism without Culture. Princeton UP.

Salfarina Abdul Gapor, Mohd. Zaini Abu Bakar, Azeem Fazwan Ahmad Farouk. 2009. Explaining Ethnic Relations in Malaysia through the "Concentric Circle Model": Case Studies of the States of Perak and Kelantan, Malaysia. European Journal of Social Sciences, Vol. 12 (2) $252-258$.

Samovar, L. \& Porter, R. 2001. Communication between Cultures. Belmont: Wadsworth

Shamsul, A.B. 1999. 'Consuming Anthropology: The Social Sciences and Nation-Formation in Malaysia.' in K. Yoshino (ed) Consuming Ethnicity and Nationalism. Honolulu: University of Hawai'i Press.

Tomlinson, J. 1999. Globalization and culture. Cambridge: Polity Press.

Wang, G 2001, 'Continuities in island Southeast Asia...' in KS Jomo (ed), Reinventing Malaysia: Reflection on its past and futur. Penerbit University Kebangsaan Malaysia, Bangi, Malaysia, pp. 15-34

Zeiny, E. \& Yusof, N.M. 2015. Deconstructing Visual Images of 1Malaysia. Research on Humanities and Social Sciences, vol 5 (13). 